\title{
Leaders
}

\section{The role of EBV in post-transplant malignancies: a review}

\author{
Paul Hopwood, Dorothy H Crawford
}

Post-transplant lymphoproliferative disorder (PTLD) is a rare but frequently fatal complication of iatrogenic immunosuppression. PTLD encompasses a spectrum of B cell lymphoproliferations ranging from reactive plasmacytic hyperplasia to monomorphic $\mathrm{B}$ cell lymphoma. ${ }^{1}$ The tumours are almost always associated with Epstein-Barr Virus (EBV), and similar lymphoproliferative disorders also occur in other congenital and acquired immunodeficiency states. ${ }^{2}$ These malignancies reflect an imbalance in the normal control of EBV infection, although the virus is also linked to a subset of Hodgkin's disease and T cell lymphomas in apparently immunocompetent individuals. ${ }^{3-5}$ Other EBV associated tumours occurring in particular areas of the world include Burkitt's lymphoma in equatorial Africa and nasopharyngeal carcinoma in South East Asia. ${ }^{2}$ This review discusses the biology of EBV infection in the normal and immunocompromised host and the risk factors and pathogenesis of EBV associated PTLD.

\section{Epstein-Barr Virus}

EBV is an enveloped herpesvirus with a $172 \mathrm{~kb}$ double stranded DNA genome. ${ }^{2}$ A defining feature of herpesviruses is their ability to maintain a latent infection with the virus genome retained in host cells without production of infectious virions. EBV targets B lymphocytes through the CD21 receptor and establishes a latent infection both in vivo and in vitro.

EBV INFECTION IN VITRO

In vitro infection of $\mathrm{B}$ lymphocytes with $\mathrm{EBV}$ results in the establishment of an immortalised B lymphoblastoid cell line in which the majority of cells contain a non-replicating episomal form of the EBV genome and only a small proportion of cells contain replicating virus. Lymphoblastoid cell lines express a panel of EBV encoded latent antigens which comprise six nuclear proteins (Epstein-Barr nuclear antigens (EBNA) 1, -2, -3A, -3B, -3C, and leader protein (LP)) and three latent membrane antigens (LMP1, -2A, and -2B). Abundantly expressed small non-polyadenylated RNAs termed Epstein-Barr virus early RNA (EBER) 1 and 2 are transcribed but not translated, and a transcript from the Bam $\mathrm{H} 1 \mathrm{~A}$ reading frame is translated into protein, although its function is still unknown. ${ }^{67}$ This pattern of EBV gene expression is termed latency III, and the immortalised phenotype of lymphoblastoid cell lines is determined by these EBV latent antigens. ${ }^{8}$ EBNA 1, -2, -3A, and -3C, EBNALP, and LMP1 are essential for host cell growth transformation. ${ }^{2}$ EBNA1 is required for maintenance of the viral genome within an infected cell, whereas EBNA2 and $-3 \mathrm{C}$ and LMP1 directly transactivate expression of cellular genes involved in normal B cell activation pathways. Thus, in contrast to cells infected with other DNA tumour viruses such as SV40 or adenovirus, which alter cell growth by interaction with cellular oncogenes or tumour suppressor genes, lymphoblastoid cell lines resemble normal proliferating B lymphocytes, albeit immortalised and with the expression of EBV encoded proteins. The pattern of EBV gene expression in lymphoblastoid cell lines and other forms of virus gene expression is shown in fig 1 .

EBV INFECTION IN VIVO

Establishment of a persistent infection is key to the life cycle of EBV in vivo. ${ }^{2}$ Over $95 \%$ of the adult population worldwide is infected with EBV, with infection usually occurring in childhood. ${ }^{19}$ Initial infection of B lymphocytes in pharyngeal lymphoid tissues follows transmission of virus through salivary exchange. In general, primary infection of healthy individuals is not accompanied by disease, although infectious mononucleosis occurs in around $50 \%$ of individuals in whom infection is delayed until adolescence. ${ }^{20}$ As infection is normally asymptomatic, studies on primary EBV infection and the development of immune responses to EBV have generally been carried out on cases of infectious mononucleosis. The florid nature of these responses probably accounts for most of the symptoms and signs of infectious mononucleosis (fever, sore throat, myalgia, fatigue, lymphadenopathy, hepatosplenomegaly) which are therefore immunopathological in nature. ${ }^{21}$

Antibodies to the early antigen complex, which comprises several immediate early and early proteins including the lytic cycle transactivator BZLF1, and to the late structural viral capsid antigen complex, develop early in infectious mononucleosis. In addition the membrane antigen complex, including the glycoprotein
Accepted for publication 17 August 1999 
Postulated phenotype of latently infected B cell in a normal EBV seropositive ${ }^{1516}$

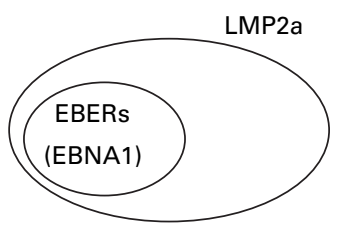

It is unclear whether EBNA1 is consistently expressed in all latently infected cells
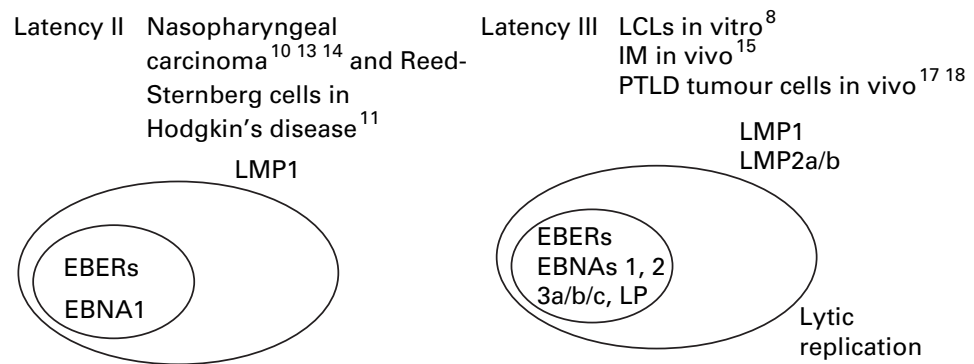

Figure 1 EBV gene expression in EBV infected cells in vivo and in vitro. EBERs, EBV encoded small RNAs; EBNA, EBV nuclear antigen; IM, infectious mononucleosis; LCL, lymphoblastoid cell line; LMP, latent membrane protein; LP, leader protein; PTLD, post-transplant lymphoproliferative disease.

gp350, induces antibodies which are neutralising. ${ }^{22}$ Thus by the onset of clinical symptoms high titres of anti-viral capsid antigen $\operatorname{IgM}$ and IgG as well as $\operatorname{IgG}$ against early antigen and membrane antigen complex can be detected. IgA against viral capsid antigen and early antigen complex may also be present transiently during this period. IgG antibodies to EBNA1, and less consistently to EBNA2, $-3 \mathrm{~A},-3 \mathrm{~B},-3 \mathrm{C}$, and LP, develop late during infectious mononucleosis and are often still rising after recovery. In addition to the EBV specific antibody response, serum heterophile antibodies can be detected in around $85 \%$ of cases of acute infectious mononucleosis. ${ }^{21}$ These form the basis of the diagnostic Paul-Bunnel and monospot tests.

The key factor in controlling EBV infection is provided by cell mediated mechanisms. A characteristic feature of infectious mononucleosis is the presence of large numbers of atypical mononuclear cells in peripheral blood and infiltrating tissues, and these are predominantly EBV specific CD8+ HLA class I restricted cytotoxic $\mathrm{T}$ lymphocytes (CTL) directed against latent and lytic cycle antigens. ${ }^{23}$

\section{PERSISTENT EBV INFECTION}

After recovery from primary infection a healthy EBV carrier state is established where IgG antibodies against viral capsid antigen, membrane antigen complex gp350, and EBNA1 are consistently detected. Titres vary between individuals but tend to remain stable. ${ }^{19}$

The presence of EBV specific memory $\mathrm{T}$ cells in normal EBV seropositive individuals was first identified through their ability to reactivate and cause regression of autologous B cell lines generated in vitro. ${ }^{24}$ This CTL memory is maintained for life with a CTL precursor frequency of at least 1 in $10^{3}$ to $10^{4}$ circulating T cells. ${ }^{25}$ The memory CTL response to EBV is mainly provided by HLA class I restricted, CD8+ cells, although some CTL activity has been identified from CD4+, HLA class II restricted cells. All EBV encoded latent antigens, with the exception of EBNA1, can be targets for CTL activity, although dominant reactivity against epitopes from EBNA3A, $-3 \mathrm{~B}$, and $-3 \mathrm{C}$ appears in a high proportion of individuals. $^{6}$

During acute infectious mononucleosis around 1 in $10^{2}$ to 1 in $10^{3}$ circulating $B$ cells in peripheral blood are infected with $\mathrm{EBV}^{26}$ and express the latency III pattern of transcription (fig 1). ${ }^{15}$ There may also be a subset of B cells in the peripheral blood containing virus undergoing lytic replication. ${ }^{27}$ However, once humoral and cellular immune responses develop these cells are eliminated, leaving a population of around 1 in $10^{6}$ circulating infected $\mathrm{B}$ cells expressing a more restricted pattern of EBV genes. ${ }^{28}$ Viral gene expression in this cell population has not been entirely clarified, although EBNA1, required for maintenance of the viral genome and not processed for antigen presentation to CTL, ${ }^{29}$ and LMP2A, which is involved in preventing reactivation, have both been detected in addition to EBER and Bam H1A RNA transcripts (fig 1). ${ }^{15} 163031$ The expression of a minimal subset of genes that are not strong targets for CTL activity allows infected cells to evade the immune system and maintain a low level persistent infection. ${ }^{32}$ The maintenance of detectable immune responses against the viral capsid antigen, membrane antigen gp350, and EBNAs suggests that EBV infected cells undergo lytic replication, with transient expression of the full panel of latent antigens followed by immune recognition and elimination in the majority of cases. Thus a dynamic flux appears to exist between latent infection and lytic replication in EBV infected $B$ cells in the face of sustained immune mechanisms. EBV is continuously or sporadically shed in saliva, providing a route of transmission ${ }^{33}$; however, the exact source of this free virus is unclear. It now seems most likely that the site of this productive infection is intraepithelial B cells in the pharynx rather than squamous epithelial cells. ${ }^{34}$

\section{Post-transplant lymphoproliferative disease (PTLD)}

In a normal EBV seropositive individual, a balance exists between viral load and immune mechanisms which maintains persistent infection at a subclinical level. However, following organ transplantation, when immunosuppressive treatment is required to prevent graft rejection, loss of CTL activity probably allows infected cells-perhaps expressing a latency III phenotype - to persist. This leads to the accumulation of EBV infected B cells in the body and enhanced virus replication. Thus following transplantation there is an increase in the level of EBV shed in saliva, in the number of EBV infected B cells in blood, and in the level of EBV DNA detectable in peripheral blood by polymerase chain reaction (PCR).$^{35-40}$ These changes mirror loss of CTL activity and return to normal when the level of 
immunosuppression is reduced. ${ }^{41}{ }^{42}$ This picture is sometimes called a "reactivated" EBV infection, although in most cases no disease ensues. However, in a minority of patients, uncontrolled EBV driven B cell proliferation occurs, leading to clinical post-transplant lymphoproliferative disease.

PATHOGENESIS OF PTLD

The incidence of PTLD varies with different types of organ transplant, being most common in intestinal and heart/lung transplant recipients, and having the lowest incidence after bone marrow transplantation. ${ }^{43}$ Overall, the disease occurs in around $1-10 \%$ of transplant recipients, is the most common malignancy in transplanted children, and is second only to squamous cell cancer in adults. ${ }^{44}$ Over $50 \%$ of PTLD cases are associated with primary EBV infection and this accounts for the particular risk to paediatric transplant recipients. ${ }^{45}{ }^{46} \mathrm{EBV}$ infection post-transplantation causes disease through inability to mount an effective immune response which brings the infection under control. Disease generally occurs in the first year post-transplant and presents as an infectious mononucleosis-like illness. Where the organ donor is EBV seropositive and the recipient EBV seronegative, the donor organ can act as the source of infection. ${ }^{47}{ }^{48}$ In contrast, most cases of PTLD occurring in previously EBV seropositive individuals do not develop for over a year, and may present many years post-transplant. ${ }^{44}$

PTLD comprises $56 \%$ of all neoplasms in bone marrow transplant recipients. ${ }^{49}$ It occurs in less than $1 \%$ of all bone marrow transplant recipients, but the frequency increases to $24 \%$ in patients receiving $\mathrm{T}$ cell depleted marrow from an HLA mismatched donor, $12 \%$ in $\mathrm{T}$ cell depleted matched donors, and $14 \%$ if the recipient receives anti-CD3 antibody. ${ }^{179-52}$ Many bone marrow transplant recipients have underlying immunodeficiencies which represent an independent risk factor for PTLD in this group, ${ }^{18}$ and following transplantation are heavily immunodeficient owing to destruction of their bone marrow by chemotherapy or radiotherapy and because of immunosuppression to treat graft versus host disease (GVHD). Following bone marrow destruction before transplantation, the recipient may lose their original EBV isolate, which provides additional evidence for $\mathrm{B}$ cells as the site of EBV persistence. ${ }^{53}$ This can result in the recipient becoming EBV negative following transplantation from an EBV seronegative donor, and perhaps subsequently undergoing reinfection through salivary transmission, or alternatively acquiring the isolate of an EBV infected donor. $^{5354}$ Ablation of the recipient's bone marrow before transplantation and reconstitution of the recipient's immune system with donor cells means that PTLD is usually of donor B cell origin. ${ }^{50}$ In contrast to solid organ transplant recipients, where PTLD can arise early or late post-transplant, PTLD generally arises early following bone marrow transplantation and is rapidly fatal. ${ }^{50}$ The risk of PTLD is increased if the bone marrow is depleted of $\mathrm{T}$ cells before infusion to reduce GVHD, as donor $\mathrm{T}$ cells would be capable of mounting a defence against the development of PTLD of donor B cell origin. ${ }^{50}$ However, if B cells are removed from the graft before transplantation ${ }^{55}$ or if the donor is depleted of $\mathrm{T}$ cells and coincidentally of B cells by counterflow elutriation, this risk factor is eliminated. ${ }^{56}$

The incidence of PTLD varies between transplant centres, probably reflecting the influence of different immunosuppressive regimes on tumour development. The introduction of cyclosporin A in 1979 was accompanied by a large increase in PTLD, ${ }^{57}$ and the addition of antithymocyte globulin (ATG) $)^{58}$ - or more recently murine anti-CD3 monoclonal antibody, $\mathrm{OKT}^{59}$ and $\mathrm{FK} 506^{60}$ - to treat rejection episodes further increased the incidence. The cumulative dose of immunomodulatory drugs plays an important part in determining the risk of disease.

Most PTLD tumour cells express the latency III pattern of EBV gene expression, with a small proportion of cells undergoing lytic replication. ${ }^{61}{ }^{62}$ As expression of the latent antigens, particularly the viral oncogenes LMP1 and EBNA2, has profound effects on the infected cell, with loss of growth control and induction of proliferation, this finding strongly suggests that EBV is directly responsible for polyclonal B cell hyperplasia and PTLD. However, the pattern of viral gene expression within a particular tumour may vary between individual cells ${ }^{63}$ and occasionally latency type I and II patterns have also been detected in PTLD biopsies. ${ }^{616465}$ In these cases additional genetic or epigenetic changes are probably required for tumour outgrowth.

PTLD often develops in sites that are unusual in the context of other lymphomas, particularly in EBV seropositive individuals with late onset disease. ${ }^{44}$ These are generally localised extranodal tumours and commonly occur in the gastrointestinal tract, central nervous system, or grafted organ, ${ }^{6066}{ }^{66}$ the latter site being most common in lung transplant recipients. ${ }^{68}$ It is therefore likely that additional factors associated with these particular organs render them favourable sites for PTLD development. The occurrence of PTLD in the transplanted organ, for example, may reflect the complex immunological interactions taking place during graft rejection or dysfunction that can enhance cytokine production. ${ }^{68} 69$

In this context a recent study suggests an association between PTLD and cytomegalovirus disease. ${ }^{70}$ This may simply reflect the combined loss of immune control for cytomegalovirus and EBV with high dose immunosuppression, but it is also possible that reactivation of cytomegalovirus has profound effects on the immune system by inducing cytokine production which directly transactivate EBV genes. ${ }^{71}$

In tumour biopsy material, EBV positive cells often make up only a modest proportion of the tumour mass, with an extensive EBV negative lymphoid infiltrate comprising predominantly CD4+ $\mathrm{T}$ lymphocytes. ${ }^{72}$ In vivo experiments in severe combined immunodeficient (SCID) mice, where PTLD-like tumours 
Table 1 Laboratory procedures for investigation of post-transplant lymphoproliferative disorder (PTLD)

\begin{tabular}{ll}
\hline Procedure & Result \\
\hline Routine histology & Lymphoma diagnosis \\
Cellular phenotyping & PTLD classification \\
EBER in situ hybridisation & EBV association \\
$\kappa, \lambda$ Polymerase chain reaction & Cellular clonality \\
EBV serology & Association with primary EBV infection \\
\hline
\end{tabular}

EBER, Epstein-Barr virus early RNA; EBV, Epstein-Barr virus.

can be generated following injection of human peripheral blood mononuclear cells, show that $\mathrm{T}$ cells are necessary for establishment of these tumours. $^{73}$ This suggests a role for the non-tumour element in PTLD development, possibly in supplying essential growth factors. Reverse transcriptase polymerase chain reaction (RT-PCR) and in situ hybridisation studies of SCID generated tumours have shown that tumour cells produce cytokines that can stimulate B cell growth in an autocrine fashion. ${ }^{74}$ Thus established tumours may not require additional growth factors, allowing greater autonomy by the tumour cells.

Progression of PTLD from polyclonal to more aggressive monoclonal lesions regularly occurs in untreated cases or in recurrent lesions, ${ }^{43}$ and probably involves additional cellular genetic changes, although data on this are inconclusive. Some studies report changes in the tumour suppressor gene p53 and oncogenes c-myc and N-ras. ${ }^{75} 76$ These changes may abrogate the need for expression of growth transforming EBV antigens, as in the case of rare EBNA2 and LMP1 negative tumours. ${ }^{6164}$

DIAGNOSIS OF PTLD

The diversity of clinical and histological presentation of PTLD can make diagnosis difficult. A common clinical presentation, particularly in early onset PTLD, is an infectious mononucleosis-like illness accompanied by fever and lymphadenopathy, and this may be mistaken for opportunistic infection or graft rejection. Similarly, late onset PTLD may present as persistent febrile illness, and in this case PTLD may be considered only after treatment for other opportunistic infections such as cytomegalovirus. ${ }^{43}$ The laboratory procedures for diagnosis of PTLD are discussed here and summarised in table 1 .

Immunohistochemical analysis of tumour biopsy material is essential to provide a definitive diagnosis of PTLD, and in situ hybridisation for detection of the abundantly expressed EBER RNAs is routinely used to determine involvement of EBV in the disease. ${ }^{1}$ These tumours show a marked degree of morphologi-

Table 2 Histological classification of post-transplant lymphoproliferative lesions (from ref 1)

(1) Early lesions including infectious mononucleosis-like reactive plasma cell hyperplasias

(2) Polymorphic PTLD, which may be polyclonal or monoclonal

(3) Monomorphic PTLD of diffuse large B cell lymphoma (immunoblastic, centroblastic, or anaplastic) or Burkitt's type

(4) T cell lymphoma

(5) Other, including Hodgkin's disease, plasmacytoma-like lesions, and myeloma

PTLD, post-transplant lymphoproliferative disorder. cal, immunophenotypic, and genetic heterogeneity and have recently been classified into five separate types, outlined in table $2 .{ }^{1}$

Detection of high levels of EBV DNA in peripheral blood mononuclear cells, while being associated with the occurrence of PTLD, is not diagnostic of disease. This is because, although high DNA levels are detected in most cases of PTLD, this is not always the case, and similar levels can be seen in patients who do not develop disease. ${ }^{3739}$ Caution must therefore be exercised in interpreting these tests. EBV DNA has also been detected in the serum of patients with PTLD. ${ }^{77}$ This finding precedes PTLD development and may be a predictive factor for the disease because-apart from the specific cases of infectious mononucleosis ${ }^{78}$ and nasopharyngeal carcinoma ${ }^{79}$ - it is apparently unique to PTLD.

Assessment of tumour cell clonality is of limited use in providing clear prognostic information in PTLD owing to the unpredictable nature of these lesions. However, polyclonal lesions tend to be more responsive to conservative treatment such as reduction of immunosuppression, whereas monoclonal tumours, which may contain additional cellular genetic changes, are often more aggressive. Owing to the risk of sampling error in determining clonality by immunohistochemistry, the preferred method is PCR to detect immunoglobulin gene rearrangements. ${ }^{80} 81$ Most cases of PTLD probably arise as polyclonal proliferations, but untreated or recurrent lesions progress to oligoclonal or monoclonal tumours. ${ }^{82}$ Multiple sites of tumour involvement may show all stages of progression, and even within an individual tumour, polyclonal proliferations can coexist with clonal populations. ${ }^{75}$

Serological analysis is of little value in the diagnosis of PTLD, and may even be misleading owing to the severe immune dysfunction in these patients. If available, testing a pretransplant serum sample will determine whether the patient was previously seronegative, and if so, then detection of $\operatorname{IgM}$ antibody against viral capsid antigen is diagnostic for primary EBV infection and suggestive of PTLD. However, EBV specific IgM and IgG antibodies, as well as heterophile antibodies, may be slow to appear and of very low titre in this patient group. In previously EBV seropositive patients, antibody titres to EBV antigens are often high, but this is common post-transplant, and reflects immunosuppression rather than PTLD specifically.

TREATMENT

Mortality from PTLD remains over 50\% despite the use of a variety of treatment strategies. Published studies tend to be small scale, anecdotal, and complicated by the diversity in presentation of PTLD and in the histological features of the cases. In general, however, as Startzl et al observed that lesions could regress spontaneously following reduction in immunosuppression, ${ }^{83}$ this is now the first line of treatment for PTLD in solid organ transplant recipients. There is no definitive classification for predicting the response of 
these tumours to reduced immunosuppression, although early onset polyclonal PTLD associated with primary EBV infection is usually more responsive than monoclonal tumours appearing in EBV seropositive individuals over one year post-transplant. ${ }^{176}$ Clearly this strategy carries with it the risk of graft rejection, so cases must be carefully monitored and treatment tailored to clinical events. High doses of the antiviral drugs acyclovir or gancyclovir are often included in the treatment, in combination with reduced immunosuppression. ${ }^{84}$ However, as these drugs only block herpes virus replication, ${ }^{85}$ their value in PTLD, where most EBV infected cells are latently infected, remains unclear. Surgical resection, irradiation, or chemotherapy are used to treat PTLD where initial reduction in immunosuppression fails. ${ }^{84}$ Interferon alfa has also been effective at inducing complete remission in both polyclonal and monoclonal lesions, although the precise mode of antitumour action is not known. ${ }^{86}$

Because of the high mortality from PTLD, new treatment strategies involving $\mathrm{T}$ cell immunotherapy are now being assessed. PTLD presents an ideal target for this type of treatment for several reasons. First, immunogenic EBV antigens are expressed only on tumour cells and not on normal cells, and therefore this treatment is specific for the tumour; second, CTL are relatively easy to culture in vitro in large numbers; third, immunotherapy carries less risk of damage or loss of the grafted organ than reduction in immunosuppression (this is of particular importance in heart/lung and liver transplants, where loss of the graft would be fatal); finally, immunotherapy is non-toxic and therefore preferable to chemotherapy.

EBV specific CTL activity can be restored in bone marrow transplant recipients through adoptive transfer of EBV specific polyclonal T cells of donor origin. ${ }^{87}$ Similarly a pilot study has shown restoration of EBV specific CTL activity in healthy EBV seropositive liver and kidney transplant recipients following infusion of in vitro expanded autologous CTL. ${ }^{88}$ The CTL were retained, remained functional for at least three months post-infusion, and caused reduction in levels of EBV DNA detectable in the blood. Advances have also been made in using chemically engineered major histocompatibility complex tetramers which could be used to enrich populations of antigen specific CTL. ${ }^{89}$ These complexes have already been used by Callan et al to directly visualise antigen specific CD8+ $\mathrm{T}$ cells during a primary immune response to EBV in vivo in humans. ${ }^{90}$

The strategy for adoptive CTL treatment in bone marrow transplant recipients is more straightforward than in solid organ transplant recipients, as in most cases the marrow donor is available. As the recipient has adopted donor lymphoid tissue, and any developing PTLD is generally of donor cell origin, CTL obtained from the donor can be used for treatment. In solid organ transplant recipients, however, where the organ is usually of cadaveric origin, autologous CTL must be grown in vitro from
$\mathrm{T}$ cells obtained before transplantation for use at a later date if PTLD should arise. This would be a costly and time consuming procedure as ideally $\mathrm{T}$ cells should be grown for each transplant recipient. An alternative strategy is to use allogeneic CTL grown from healthy donors on a best HLA match basis. ${ }^{81}$ This strategy is now being developed by Haque in our laboratory, such that a panel of frozen HLA typed, EBV specific CTL is banked and ready to infuse into patients with PTLD.

1 Harris NL, Ferry JA, Swerdlow SH. Posttransplant lymphoproliferative disorders: summary of Society for Haematopathology workshop. Semin Diagn Pathol 1997;14:8-14

2 Rickinson AB, Kieff E. Epstein Barr virus. In: Fields BN, Rickinson AB, Kieff E. Epstein Barr virus. In: Fields BN,
Knipe DM, Howley PM, eds. Fields virology, 3rd ed. Knipe DM, Howley PM, eds. Fields virology,
Philadelphia: Lippincott-Raven, 1996:2397-446.

3 Pallessen G, Hamilton-Dutoit SJ, Rowe M, et al. Expression Pallessen G, Hamilton-Dutoit SJ, Rowe M, et al. Expression of Epstein-Barr virus latent gene products in
of Hodgkin's disease. Lancet 1991;337:320-2.

4 Weiss LM, Movahed LA, Warnke RA, et al. Detection of Epstein-Barr viral genomes in Reed-Sternberg cells of Hodgkin's disease. N Engl f Med 1989;320:502-6.

5 Ott G, Ott MM, Feller AC, et al. Prevalence of Epstein-Barr virus DNA in different T-cell lymphoma entities in a European population. Int $\mathcal{F}$ Cancer 1992;51:562-7.

6 Kieff E. Epstein Barr virus. In: Fields BN, Knipe DM, Howley PM, eds. Fields virology, 3rd ed. Philadelphia: Lippincott-Raven, 1996:2343-96.

7 Fries KL, Sculley TB, Webster-Cyriaque J, et al. Identification of a novel protein encoded by the Bam H1 A region of the Epstein-Barr virus. F Virol 1997;71:2765-71.

8 Kerr BM, Lear AL, Rowe M, et al. Three transcriptionally distinct forms of Epstein-Barr virus latency insomatic cell hybrids: cell phenotype dependence of virus promoter usage. Virology 1992;187:189-201.

9 Sample J, Brooks L, Sample C, et al. Restricted Epstein-Barr virus protein expression in Burkitt's lymphoma is due to a different Epstein-Barr nuclear antigen 1 transcriptional initiation site. Proc Natl Acad Sci USA 1991;88:6343-7.

10 Brooks L, Yao QY, Rickinson AB, et al. Epstein-Barr virus latent gene transcription in nasopharyngeal carcinoma cell: coexpression of EBNA1, LMP1 and LMP2 transcripts. $f$ Virol 1992;66:2689-97.

11 Deacon EM, Pallessen G, Niedobitek G, et al. Epstein-Barr virus and Hodgkin's disease: transcriptional analysis of virus and Hodgkin's disease: transcriptional analysis of virus latenc. 49.

12 Magrath I. The pathogenesis of Burkitt's lymphoma. In: Vaude Woude GF, Klein G, eds. Advances in cancer research, vol 55. New York: Academic Press, 1990:130-270.

13 Dawson CW, Rickinson AB, Young LS. Epstein-Barr virus latent membrane protein inhibits human epithelial cell differentiation. Nature 1990;344:777-80.

14 Nicholson LJ, Hopwood PA, Johannessen I, et al. EpsteinBarr virus latent membrane protein does not inhibit differentiation and induces tumorigenicity of human epithelial cells. Oncogene 1997;15:275-83.

15 Tierney RJ, Steven N, Young LS, et al. Epstein-Barr virus latency in blood mononuclear cells: analysis of viral gene transcription during primary infection and in the carrier transcription during primary 17.

16 Miyashita EM, Yang B, Lam KM, et al. A novel form of Epstein-Barr virus latency in normal B-cells in vivo. Cell Epstein-Barr virus

17 Banckerrou M, Durandy A, Fischer A. Therapy for transplanted lymphoproliferative diseases. Hematol Oncol Clin North Am 1993;7:467-75.

18 Bhatia S, Ramsay NKC, Steinbuch M, et al. Malignant neoplasms following bone marrow transplantation. Blood 1996;87:3633-9.

19 Henle G, Henle W. Seroepidemiology of the virus. In: Epstein MA, Achong BG, eds. The Epstein-Barr virus. Berlin: Springer-Verlag, 1979:297-320.

20 Sawyer RN, Evans AS, Neiderman JC, et al. Prospective study of a group of Yale University freshman. I. Occurrence of infectious mononucleosis. F Infect Dis 1971;123:263-70.

21 Epstein MA, Crawford DH. Gammaherpesviruses: EpsteinBarr virus. In: Mahy BWJ, Collier L, eds. Microbiology and microbial infections, vol 1. London: Arnold, 1998:351-66.

22 Thorley-Lawson DA, Geilinger K. Monoclonal antibodies against the major glycoprotein (g350/220) of Epstein-Barr virus neutralise infectivity. Proc Natl Acad Sci USA 1980;77:5307-11.

23 Callan MFC, Steven N, Krausa P, et al. Large clonal expansion of CD8+ve T-cells in acute mononucleosis. Nature Med 1996;2:906-10

24 Moss DJ, Rickinson AB, Pope JH. Long-term T-cell mediated immunity to Epstein-Barr virus in man. I. Complete regression of virus-induced transformation in cultures of regression of viruse donor leukocytes. Int f Cancer 1978;24:662-8.

25 Steven N, Leese AM, Annels NE, et al. Epitope focussing in the primary cytotoxic T-cell response to Epstein-Barr virus and its relationship to T-cell memory. $\mathcal{F}$ Exp Med 1996;184: 1801-6. 
26 Svedmyr E, Ernberg I, Seeley J, et al. Virologic, immunologic, and clinical observations on a patient during the incubation, acute and convalescent phases of infectio mononucleosis. F Clin Immunopathol 1984,30.437-50.

27 Prang NS, Hornef MW, Jager M, et al. Lytic replication of Epstein-Barr virus in the peripheral blood: analysis of vira gene expression in B-lymphocytes during infectious mononucleosis and in the normal carrier state. Blood 1997;89: 1665-77

28 Miyashita EM, Yang B, Babcock GJ, et al. Identification of the site of Epstein-Barr virus persistence in vivo as a resting B cell. F Virol 1997;71:4882-91.

29 Levitskaya J, Coram M, Levitsky V, et al. Inhibition of antigen processing by the internal repeat region of the EpsteinBarr virus nuclear antigen 1. Nature 1995;375:685-8.

30 Miller CL, Lee J, Keiff E, et al. An integral membrane protein (LMP2A) blocks reactivation of Epstein Barr virus from latency following surface immunoglobulin crosslinkfrom latency following surface immunoglob

$31 \mathrm{Qu} \mathrm{L}$, Rowe DT. Epstein Barr virus latent gene expression in uncultured peripheral blood lymphocytes. $\mathcal{F}$ Virol 1992 ; 66:3715-24.

32 Lewin N, Aman P, Masucci MG, et al. Characterisation of Epstein-Barr virus carrying B-cell populations in healthy seropositive individuals with regard to density, release of transforming virus and spontaneous outgrowth. Int $\mathrm{f}$ Can cer 1987;39:472-6.

33 Yao QY, Rowe M, Martin B, et al. The Epstein-Barr virus carrier state: dominance of a single growth-transforming isolate in the blood and in the oropharynx of healthy virus carriers. f Gen Virol 1991;72:1579-90.

34 Faulkner GC, Burrows SR, Khanna R, et al. X-linked agammaglobulinaemia patients are not infected with EpsteinBarr virus: implications for the biology of the virus. F Virol 1999;73:1555-64.

35 Wagner HJ, Bein G, Bitsch A, et al. Detection and quantitation of latently infected B-lymphocytes in Epstein-Barr virus seropositive healthy individuals by polymerase chain reaction

36 Preiksaitis JK, Diaz-Mitoma F, Mirazayans F, et al. Quantitative oropharyngeal Epstein-Barr virus shedding in renal and cardiac transplant recipients: relationship to immunosuppressive therapy, serological responses, and the risk of post-transplant lymphoproliferative disorder. $\mathcal{F}$ Infect $D i$ 1992;166:986-94

37 Savoie A, Perpete C, Carpentier L, et al. Direct correlation between the load of Epstein-Barr virus infected lymphocytes in the peripheral blood of paediatric transplant recipients and risk of lymphoproliferative disease. Blood 1994;83:2715-22.

38 Riddler SA, Breinig MC, McKnight JLC. Increased levels of circulating Epstein-Barr virus-infected lymphocytes and decreased Epstein-Barr virus nuclear antigen antibody responses are associated with the development of postresponses are associated with the development of posttransplant lymphoproliferative disease

plant recipients. Blood 1994;84:972-84.
39 Kenagy DN, Schlesinger Y, Weck K, et al. Epstein-Barr virus DNA in peripheral blood of patients with posttransplant lymphoproliferative disease. Transplantation 1995;60:54754.

40 Rowe DT, Qu L, Reyes J, et al. Use of QC PCR to measure EBV genome load in peripheral blood of pediatric transplant patients with lymphoproliferative disease. 7 Clin Microbiol 1997;35:1612-15.

41 Crawford DH, Edwards JMB, Sweeny P, et al. Studies on long-term T-cell mediated immunity to Epstein-Barr virus in immunosuppressed renal allograft recipients. Int 7 Cancer 1981;28:705-9.

42 Haque T, Thomas JA, Parratt R, et al. A prospective study in heart and lung transplant recipients correlating persistent EBV infectic

43 Nalesnik MA. Clinical and pathological features of posttransplant lymphoproliferative disorders (PTLD). Springe Semin Immunopathol 1998;29:325-42.

44 Penn I. The problem of cancer in organ transplant recipients: an overview. Transplant Sci 1994;4:23-32.

45 Ho M, Miller G, Atchison RW, et al. Epstein-Barr virus infections and DNA hybridisation studies in posttransplantation lymphoma and lymphoproliferative lesions: the role of primary infection. F Infect Dis 1985;152:876-86.

46 Penn I. De novo tumours in pediatric organ transplant recipients. Transpl Proc 1991;26:1-2.

47 Cen H, Breining MC, Atchison RW, et al. Epstein-Barr virus transmission via donor organs. 7 Virol 1991;65:976-80.

48 Haque T, Thomas JA, Falk KI, et al. Transmission of donor Epstein-Barr virus in transplanted organs causes lymphoproliferative disease in EBV seronegative recipients. $\mathcal{F}$ Gen Virol 1996;77:1169-72.

49 Nalesnik MA, Locker J, Jaffe R. Experience with posttransplant lymphoproliferative disorders in solid organ transplant recipients. Clin Transplant 1992;6:249-55.

50 Shapiro RS, McClain K, Frizzera G, et al. Epstein-Bar virus-associated $\mathrm{B}$ cell lymphoproliferative disorders following bone marrow transplantation. Blood 1988;72:123443.

51 Zutter MM, Martin PJ, Sale GE, et al. Epstein-Barr virus lymphoproliferation after bone marrow transplantation. Blood 1988;72:520-9.

52 Witherspoon RP, Fisher LD, Schoch G, et al. Secondary cancers after bone marrow transplantation for leukemia or cancers after bone marrow transplantation for le

53 Gratama JW, Oosterveer MAP, Zwann FE, et al. Eradication of Epstein-Barr virus by allogeneic bone marrow transplantation: implications for the site of viral latency. Proc Natl Acad Sci USA 1988;85:8693-9.

54 Gratama JW, Oosterveer MAP, Lepoutre JMM, et al. Serological and molecular studies of EBV infection in allogeneic marrow graft recipients. Transplantation 1990;49: 725-30.

55 Cavazzana-Calpo $\mathrm{M}$, Bensoussan $\mathrm{D}$, Jabado $\mathrm{N}$, et al. Prevention of Epstein-Barr virus induced B-lymphoproliferative disease by ex-vivo marrow B-cell depletion in HLA phenoidentical or non-identical 1998;103:543-51.

56 Gross TG, Hinrichs SH, Davis JR. Depletion of EBV infected cells in donor marrow by counterflow elutriation. Exp Hematol 1998;26:395-9.

57 Penn I. Immunosuppression and neoplasia: cancers after cyclosporin therapy. Transplant Proc 1988;20:276-9.

58 Sokal EM, Antunes H, Beguin C, et al 1997. Early signs and risk factors for the increased incidence of Epstein-Barr virus related post-transplant lymphoproliferative disease in pediatric liver transplant patients treated with tacrolimus. Transplantation 1997;64:1438-41.

59 Swinnen LJ, Constanzo-Nordin MR, Fisher SG, et al. Increased incidence of lymphoproliferative disorder after immunosuppression with the monoclonal antibody OKT3 in cardiac transplant recipients. $N$ Engl f Med 1990;323: 1723-8

60 Nalesnik MA, Deetris AJ, Fung JJ, et al. Lymphoproliferative diseases arising under immunosuppression with FK506: initial observations in a large transplant population.. Transplant Proc 1991;23:1 108-10.

61 Rea D, Fourcade C, Leblond V, et al. Patterns of Epstein-Barr virus latent and replicative gene expression in Epstein-Barr virus B cell lymphoproliferative disorders after organ transplantation. Transplantation 1994;58:31724

62 Thomas JA, Hotchin NA, Allday MJ, et al. Immunohistology of Epstein-Barr virus associated antigens in B cell disorders from immunocompromised individuals. Transplantation 1990;49:944-53.

63 Cen H, Williams PA, McWilliams HP, et al. Evidence for restricted Epstein-Barr virus latent gene expression and anti-EBNA antibody response in solid organ transplant recipients with posttransplant lymphoproliferative disorders. Blood 1993;81:1393-403.

64 Hunt BJ, Thomas JA, Burke M. Epstein-Barr virus associated Burkitt's lymphoma in a heart transplant recipient. Transplantation 1996;62:869-72.

65 Oudjens JJ, Jiwa M, van den Brule AJC, et al. Detection of heterogenous Epstein-Barr virus gene expression within individual post-transplant lymphoproliferative disease. $\mathrm{Am}$ f Pathol 1995;147:923-33.

66 Penn I, Porat G. Central nervous system lymphomas in organ allograft recipients. Transplantation 1995;59:240-4.

67 Cohen JI. Epstein-Barr virus lymphoproliferative disease associated with acquired immunodeficiency. Medicine 1991;70:137-60

68 Tosato G, Jones $\mathrm{K}$, Breinig MK, et al. Interleukin 6 production in posttransplant lymphoproliferative disease. $\mathcal{F}$ Clin Invest 1993;91:2806-14.

69 Wakasugi H, Rimsky L, Mahe Y, et al. Epstein-Barr virus containing B-cell line produces an interleukin I that it uses as a growth factor. Proc Natl Acad Sci USA 1987;84: 804-8.

70 Manez R, Breining MC, Linden P, et al. Posttransplant lymphoproliferative disease in primary Epstein-Barr virus infection after liver transplantation: the role

71 Aalto SM, Linnavuori K, Peltola $\mathrm{H}$, et al. Immunoreactivation of Epstein-Barr virus due to cytomegalovirus primary infection. $\mathcal{7}$ Med Virol 1998;56:186-91.

72 Perera SM, Thomas JA, Burke M, et al. Analysis of the T-cell microenvironment in Epstein-Barr virus-related post-
transplantation B-lymphoproliferative disease. 7 Pathol 1998;184:177-84.

73 Veronese ML, Veronesi A, D'Anrea E, et al. Lymphoproliferative disease in human peripheral blood mononuclear cell-injected SCID mice. I. T lymphocyte requirement of B-cell tumour generation. $\mathcal{F}$ Exp Med 1992;196:1763-7.

74 Johannessen I, Crawford DH. In vivo models for EpsteinBarr virus associated B-cell lymphoproliferative disease. Rev Med Virol 1999;9:263-77.

75 Knowles DM, Ceserman E, Chadburn A, et al. Corrective morphologic and molecular genetic analysis demonstrates three distinct categories of post-transplantation lymphoproliferative disorders. Blood 1995;85:552-65.

76 Chadburn A, Ceserman E, Knowles DM. Molecular pathology of post-transplantation lymphoproliferative disorders. Semin Diagn Pathol 1997;14:15-26.

77 Scichman SA, Gulley ML, Hamilton E, et al. EBV DNA quantitation in serum is highly correlated with development and regression of post-transplant lymphoproliferative disorder in solid organ transplant recipients. Presented at the 8th International meeting of the EBV Association: Symposium on Tumour Associated Herpesviruses, Stockholm, Sweden, 1998 [abstract 6]

78 Gan Y, Sullivan JL, Sixbey JW. Detection of cell free Epstein-Barr virus in serum during acute infectious mononucleosis. F Infect Dis 1994;170:436-9.

79 Yamamoto M, Kimura H, Hironaka T, et al. Detection and quantification of virus DNA in plasma of patients with Epstein-Barr virus associated diseases. F Clin Microbiol
1995;33:1765-8. 
80 Hanto DW, Birkenbach M, Frizzera G, et al. Confirmation of the heterogeneity of post-transplant Epstein-Barr virusassociated B-cell proliferations by immunoglobulin gene rearrangement analysis. Transplantation 1989;47:458-64.

81 Trainor KJ, Brisco MJ, Wan JH, et al. Gene rearrangement in $\mathrm{B}$ and $\mathrm{T}$ cell lymphoproliferative disease detected by polymerase chain reaction. Blood 1991;78:192-6.

82 Nalesnik MA, Locker J, Jaffe R, et al. Clonal characteristics of posttransplant lymphoproliferative disorders. Transplant Proc 1988;20:280-3.

83 Startzl TE, Nalesnik MA, Porter KA, et al. Reversibility of lymphomas and lymphoproliferative lesions developing
under cyclosporine-steroid therapy. Lancet 1984;i:584-7.

84 Davis CL. The antiviral prophylaxis of post-transplant lymphoproliferative disorder. Springer Semin Immunopathol 1998;20:437-54.

85 Lin JC, Smith MC, Pagano JS. Induction of replication of Epstein-Barr virus DNA by 12-o-teradodecanoyl-phorbolhydroxyethoxymethylguanine. Virology 1981;11:294-8.
86 Faro A. Interferon alpha and its effects on post-transplant lymphoproliferative disorders. Springer Semin Immunlymphoproliferative dis

87 Rooney CM, Smith Ca, Ng CYC, et al. Use of gene modified virus-specific T-lymphocytes to control Epstein-Barr virusrelated lymphoproliferation. Lancet 1995;345:9-12.

88 Haque T, Amlot PL, Helling N, et al. Reconstitution of EBV specific T-cell immunity in solid organ transplant recipients. F Immunol 1998;160:6204-9.

89 Altman JD, Moss PA, Goulder PJR, et al. Phenotypic analysis of antigen specific T-lymphocytes. Science 1996;274:94-6.

90 Callan MFG, Tan L, Annels N, et al. Direct visualisation of antigen-specific CD8+ve T-cells during primary immune response to Epstein-Barr virus in vivo. $\mathcal{f}$ Exp $\mathrm{Med}$ 1998;187:1395-402.

91 Haque T, Crawford DH. Role of adoptive immunotherapy in the prevention and treatment of lymphoproliferative disease following transplantation. Br f Haematol 1999;106: 309-16.

\section{Fournal of Clinical Pathology - http://www.jclinpath.com}

Visitors to the world wide web can now access the fournal of Clinical Pathology either through the BMJ Publishing Group's home page (http://www.bmjpg.com) or directly by using its individual URL (http://www.jclinpath.com). There they will find the following:

- Current contents list for the journal

- Contents lists of previous issues

- Members of the editorial board

- Information for subscribers

- Instructions for authors

- Details of reprint services

- Instructions for use of Pathology Interactive.

A hotlink gives access to:

- BMJ Publishing Group home page

- British Medical Association web site

- Online books catalogue

- BMJ Publishing Group books.

The web site is at a preliminary stage and there are plans to develop it into a more sophisticated site. Suggestions from visitors about features they would like to see are welcomed. They can be left via the opening page of the BMJ Publishing Group site or, alternatively, via the journal page, through "about this site". 